\title{
Optimalisasi Program Pengembangan Keprofesian Berkelanjutan untuk Meningkatkan Kinerja Guru Pendidikan Agama Islam
}

Optimization the Continuous Professional Development Program to

Improve the Performance of Islamic Religious Education Teachers

\author{
Elih Yuliah
}

Kementerian Agama Kota Sukabumi

elih.yuliah67@gmail.com

\begin{abstract}
Abstrak
Peningkatan kompetensi Guru PAI di Kota Sukabumi salah satunya dilakukan dengan Program Pengembangan Keprofesian Berkelanjutan (PKB). Asumsinya adalah program tersebut dapat meningkatkan kinerja. Oleh karena itu penelitian ini bertujuan untuk mendeskripsikan upaya optimalisasi program pengembangan keprofesian berkelanjutan pada Guru PAI. Penelitian ini menggunakan metode penelitian deskriptif kualitatif. Subjek penelitian adalah Guru PAI di Kota Sukabumi. Analisis data dalam penelitian ini menggunakan analisis kualitatif. Penelitian ini menghasilkan tawaran gagasan mengenai optimalisasi PPKB yaitu melalui beberapa tahap berikut (1) Evaluasi diri; (2) Penyusunan profil guru berdasarkan capaian awal; (3) Pengembangan PPKB guru PAI dengan beberapa tahapan pelatihan; (4) Pelaksanaan PPKB PAI sesuai sesuai dengan ketercapaian penilaian awal yang menggambarkan profil guru PAI; (5) Pengawas PAI melakukan evaluasi terhadap implementasi PPKB. Kesimpulan penelitian ini menunjukkan bahwa PPKB dapat meningkatkan kompetensi dan kinerja Guru PAI secara terukur, sistematis, dan berkelanjutan.

Kata Kunci: Guru, Pendidikan Agama Islam \& Pengembangan Keprofesian Berkelanjutan
\end{abstract}

\begin{abstract}
One of the ways to increase the competence of PAI teachers in Sukabumi City is the Continuous Professional Development Program. The assumption is that the program can improve performance. Therefore, this research aims to describe efforts to optimization the continuous professional development program for Islamic religious education teacher. This research uses descriptive qualitative research method. The subject of the study was an Islamic Education teacher in Sukabumi City. Data analysis in this research used qualitative analysis. This research resulted in an offer of ideas regarding the optimization of PPKB through the following stages (1) Self-evaluation; (2) Preparation of teacher profiles based on initial achievements; (3) Development of continuous professional development program of Islamic religious education teacher with several stages of training; (4) The implementation of continuous professional development program of Islamic religious education teacher in accordance with
\end{abstract}

Jurnal At-Tadbir: Media Hukum dan Pendidikan Volume 31 Nomor 2 Tahun 2021 
the achievement of the initial assessment that describes the profile of Islamic religious education teacher; (5) The supervisors of Islamic religious education teacher evaluate the implementation of continuous professional development program. The conclusion of this research that continuous professional development program can improve the competence and performance of Islamic religious education teacher in a measurable, systematic, and sustainable way. Keywords: Teachers, Islamic Religious Education \& Continuous Professional Development

\section{PENDAHULUAN}

Program Pengembangan Keprofesian Berkelanjutan (PKB) guru menjadi salah satu langkah dalam pengembangan profesionalisme (Rahyasih dkk, 2020). Guru sering mengharapkan bahwa perubahan pada adminsitrasi cenderung jauh dari kebutuhan dan permasalahan. Penggiringan pada norma selanjutnya akan menjadi langkah yang besar dalam perubahan, sebagaimana dijelaskan pada www.learningfirst.org,

Teachers often expect that change will be mandated from an administration that is distant from their needs and problems. Departure from this norm would be a great step forward. To engage teachers more fully in their own professional development.

$$
\text { Pelaksanaan Pendidikan }
$$
Agama Islam (PAI) yang berlangsung di sekolah saat ini masih dianggap kurang berhasil dalam mengelola sikap dan perilaku keberagamaan peserta didik serta membangun moral dan etika bangsa. Indikator kelemahan yang melekat pada pelaksanaan pendidikan agama di sekolah, dapat diidentifikasi sebagai berikut:1) PAI kurang bisa mengubah pengetahuan agama yang kognitif menjadi"makna"dan"nilai" atau kurang mendorong penjiwaan terhadap nilai-nilai keagamaan yang perlu diinternalisasikan dalam diri peserta didik; 2) PAI kurang dapat berjalan bersama dan bekerja sama dengan program pendidikan nonagama; 3) PAI kurang mempunyai relevansi terhadap perubahan sosial yang terjadi di masyarakat atau kurang ilustrasi konteks sosial budaya (Muhaimin, 2013).

Sertifikasi diperuntukkan bagi guru atau pendidik agar 
mereka lebih fokus dan berhasil dalam mendidik para siswanya melalui sistem belajar mengajar di sekolah yang sudah ditentukan oleh pemerintah sebagai tempat pembelajaran untuk anak didik. UU Sisdiknas No. 20Tahun 2003 sebagai bentuk implementasi dari Pembukaan UUD 1945, yang memuat tujuan pendidikan adalah, "untuk berkembangnya potensi peserta didik agar menjadi manusia yang beriman dan bertakwa kepada Tuhan Yang Maha Esa, berakhlak mulia, sehat, berilmu, cakap, kreatif, mandiri, dan menjadi warganegara yang demokratis dan bertanggung-jawab".

Diakui bahwa terdapat beberapa kesulitan dalam pelaksanaan Pendidikan Agama Islam, baik yang bersifat internal maupun eksternal. Kesulitan internal, berasal dari sifat bidang studi PAI itu sendiri yang banyak menyentuh aspek-aspek metafisika dan bersifat abstrak, atau menyangkut hal-hal yang bersifat supra rasional. Sedangkan kesulitan eksternal berasal dari luar studi PAI itu sendiri, antara lain menyangkut dedikasi Guru PAI mulai menurun, lebih bersifat transaksional dalam bekerja.
Rendahnya profesionalisme guru tidak lepas dari beberapa faktor yang mengitari. Pandangan ini pernah dikemukakan oleh Ani M Hasan yang menyatakan bahwa faktor-faktor yang menyebabkan rendahnya profesionalisme guru antara lain (Dasuki, 2010):

1. Masih banyak guru yang tidak menekuni profesinya secara utuh. Hal ini disebabkan oleh banyak guru yang bekerja di luar jam kerjanya untuk memenuhi kebutuhan hidup sehari-hari sehingga waktu untuk membaca dan menulis untuk meningkatkan diri tidak ada;

2. Kurangnya motivasi guru dalam meningkatkan kualitas diri karena guru tidak dituntut untuk meneliti sebagaimana yang diberlakukan pada dosen di perguruan tinggi.

Selain permasalahan di atas, pembelajaran PAI dalam konteks kompetensi guru, mempunyai beberapa masalah, di antaranya adalah (Direktorat Pendidikan Agama Islam, 2016):

1. Guru PAI lebih terkonsentrasi persoalan-persoalan teoritis keilmuan yang bersifat kognitif semata dan lebih menekankan 
pada

pekerjaan mengajar/transfer ilmu;

2. Metodologi pembelajaran PAI selama ini secara umum tidak kunjung berubah, ia bagaikan secara konvensional-tradisional dan monoton sehingga membosankan peserta didik;

3. Pelajaran PAI seringkali dilaksanakan di sekolah bersifat menyendiri, kurang terintegrasi dengan bidang studi yang lain, sehingga mata pelajaran yang diajarkan bersifat marjinal dan periferal;

4. Pembelajaran PAI seringkali terkonsentrasi dalam kelas dan enggan untuk dilakukan kegiatan praktek dan penelitian di luar kelas;

5. Penggunaan media pembelajaran baik yang dilakukan guru maupun peserta didik kurang kreatif, variatif dan menyenangkan;

6. Pembelajaran PAI cenderung normatif, linier, tanpa ilustrasi konteks sosial budaya dimana lingkungan peserta didik tersebut berada, atau dapat dihubungkan dengan perkembangan zaman yang sangat cepat perubahannya;
7. Kurang adanya komunikasi dan kerjasama dengan orangtua dalam menangani permasalahan yang dihadapi peserta didik.

Sejalan dengan hasil penelitian tentang keahlian Guru PAI di kota Sukabumi, penulis mengutip pemikiran Muhaimin (2011) bahwa profesionalisme dengan suatu pekerjaan atau jabatan ditentukan oleh tiga faktor penting, yaitu:

1. Memiliki keahlian khusus yang dipersiapkan oleh program pendidikan atau spesialisasi;

2. Kemampuan untuk memperbaiki keterampilan khusus yang dimilikinya;

3. Penghasilan yang memadai sebagai imbalan terhadap keahlian yang dimiliki itu.

Pemikiran di atas melahirkan kontruksi bahwa profesionalisme guru harus didukung oleh heahlian dan kemampuan khusus serta selalu mengadakan

peningkatan kemampuan secara berkelanjutan sehingga mendapatkan upah dan gaji sesuai ketentuan dan aturan yang berlaku yang ditetepkan pemerintah. Puncak dari upaya ini akan timbul keyakinan sebagai guru professional. Hal tersebut sebagaimana menurut Ramli 
(2005) dalam suatu survei, sebanyak $80 \%$ dari manajer Amerika berpendapat bahwa keyakinan terhadap kualitas akan menjadi sumber fundamental keunggulan bersaing di abad 21 . Seseorang yang yakin dengan ilmunya, kualitas diri dan berupaya mengembangkan diri akan eksis dan mampu mengaktualisasikan dirinya, sehingga orang yang di sekitarnya akan menghargai dan memberi kesempatan untuk maju menuai prestasi.

Setelah melakukan survey sederhana di lapangan sebagian kecil Guru PAI yang telah menguasai ICT hanya sedikit. Data ini diperoleh lakukan ketika Kementeriaan Agama dalam hal ini Kasi PAIS Kota Sukabumi mengadakan Lomba Pembelajaran PAI berbasis ICT dari jumlah Guru PAI 450 mulai jenjang SD/SMP,SMA/SMK yang mengikuti lomba hanya 12 orang dengan persentase $1,2 \%$. Fenomena seperti ini menunjukkan tingkat mutu dan profesionalisme Guru PAI Kota Sukabumi yang masih rendah.

Berdasarkan hasil studi orientasi pada Kementerian Agama Kota Sukabumi Seksi PAIS dan
Pengawas Pendidikan Agama Islam tanggal 27 Desember 2016 diperoleh informasi mengenai kondisi riil permasalahan yang berkaitan dengan tenaga pendidik Guru PAI pada Sekolah umum di Kota Sukabumi di antaranya adalah (Subhan, 2017):

1. Banyak guru pada sekolah umum negeri dan sekolah umum swasta yang sudah lulus uji kompetensi dalam program sertifikasi terutama para Guru PAI PNS tetapi kinerjanya belum maksimal dan lebih berhasil guru-guru non PNS;

2. Keragaman kompetensi guru dalam proses pembelajaran;

3. Pembinaan yang dilakukan oleh kepala sekolah dan pengawas belum mencerminkan aspek kebutuhan secara spesifik;

4. Kesejahteraan guru yang belum memadai.

5. Kualifikasi akademikyang kurang relevan dengan kelayakan mengajar.

6. Kurangnya motivasi kesadaran diri guru untuk melakukan suatu perubahan terutama dalam kegiatan proses pembelajaran;

7. Banyak guru yang telah disertifikasi namun belum 
menunjukkan kinerjanya dengan baik;

8. Rendahnya etos kerja guru;

9. Pembinaan profesi berkelanjutan non PNS lebih berhasil dari pada guru PNS.

Masalah-masalah ini menggambarkan tentang lemahnya kinerja guru.

Terkait dengan fenomena di atas, problem pada penelitian ini di antaranya berkaitan dengan:

1. Kompetensi guru dalam menyusun karya tulis ilmiah dalam bentuk publikasi ilmiah;

2. Perwujudan kompetensi profesional yang rendah;

3. Kinerja guru yang lemah;

4. Pengembangan keprofesionalan berlanjut belum menunjukkan hasil yang maksimal;

5. Kelemahan dalam pengembangan pembelajaran sebagai salah satu aspek kompetensi pedagogik;

6. Kegiatan atau program pelatihan yang diselenggarakan pemerintah maupun yang dilakukan secara swadana guru selama ini yang menyangkut PTK bagi guru masih sangat kurang;

7. Pelatihan-pelatihan PTK bagi guru yang dilaksanakan sejauh ini masih dominan pada tataran teori atau konsep, belum banyak yang praktis;

8. Belum efektifnya pembinaan Dinas Pendidikan dan Kebudayaan, KKG/MGMP, dan pihak sekolah dalam mengelola dan melaksanakan PKB guru.

Berdasarkan latar belakang masalah tersebut, peneliti menentukan fockus penelitian pada upaya optimalisasi program pengembangan Keprofesian Berkelanjutan (PKB) untuk meningkatkan kinerja Guru PAI

\section{METODE PENELITIAN}

Penelitian ini menggunakan metode penelitian deskriptif kualitatif yaitu rangkaian kegiatan untuk memperoleh data yang bersifat apa adanya tanpa ada dalam kondisi tertentu yang hasilnya lebih menekankan makna dengan tujuan untuk dapat mengeksplor upaya optimalisasi program pengembangan keprofesian berkelanjutan pada Guru PAI.

Subjek penelitiannya adalah Guru PAI PNS se-Kota Sukabumi. Data awal untuk pengujian PK online sebanyak 67 orang. Adapun untuk program pengembangan PKB PAI sebanyak 20 orang. 
pengumpulan data dalam penelitian ini digunakan teknik observasi, wawancara, dan dokumentasi.

Analisis kualitatif dilakukan dengan melakukan deskripsi terhadap informasi data kualitatif. Data kualitatif yang dimaksud adalah data yang diperoleh dari kegiatan observasi/ wawancara, kegiatan FGD dan saran saran hasil konsultasi dengan pakar.

\section{HASIL DAN PEMBAHASAN \\ Model PKB guru PAI} dirancang dengan beberapa tahapan tertentu baik pada aspek prosedural maupun konseptual (materi sajian). Guru PAI pada jenjang SD, SMP, SMA dan SMK melaksanakan evaluasi diri sebagai upaya pemetaan kompetensi awal. Evaluasi diri ini didesain dengan menggunakan aplikasi Microsoft Excel dengan sajian beberapa kompetensi inti guru PAI terutama berdasarkan KMA Nomor 211 Tahun 2011 tentang Standar Nasional PAI pada Sekolah. Penilai PKG, dalam hal ini unit terdekatnya adalah Pokjawas atau personal Pengawas PAI sesuai jenjang satuan pendidikan. Analisis terhadap penilaian ini diarahkan untuk penyusunan profil guru berdasarkan capaian penilaian awal. Peneliti, penilai PKG guru, dan MGMP PAI pada setiap jenjang satuan pendidikan menyusun program perencanaan PKB. Guru PAI melaksanakan PKB sesuai dengan ketercapaian penilaian awal yang menggambarkan profil guru PAI. Peneliti dan penilaian PKG (pengawas PAI) melaksanakan monitoring implementasi hasil PKB. Penilai PKG melaksanakan penilaian kinerja pada akhrir tahun sesuai dengan jenjang satuan pendidikan.

Evaluasi diri didesain dengan menggunakan aplikasi yang dapat diisi langsung oleh guru. Aplikasi ini didesain dengan ketersambungan pengisian data pada setiap jendela program. Penggunaan hyperlink dipandang memudahkan guru PAI untuk mengisi setiap data yang dibutuhkan pada evaluasi diri. Ketercapaian nilai PK Guru PAI ini dijadikan dasar dalam menyusun profil guru. Pada konteks evaluasi diri ini, penilai memberitahukan kepada guru yang dinilai tentang nilai hasil PK Guru berdasarkan bukti catatan untuk setiap kompetensi. 
Peneliti menyusun desain pemetaan kompetensi pula untuk pemetaan profil guru. Pemetaan kompetensi berisi mengenai soalsoal pengetahuan yang berhubungan dengan enam kompetensi guru PAI berdasarkan KMA Nomor 211 Tahun 2011. Aksesibilitas pengisian kompetensi ini mengadopsi sistem yang digunakan oleh Direktorat Pendidikan Agama Islam Kemenag melalui Tim PPKB PAI. Pemetaan kompetensi menggunakan piranti Adobe Flash Versi 11.

Tahapan uji coba diawali dengan produk yang dikembangkan dalam penelitian ini melalui prosedur pengembangan. Uji keterbacaan model PKB dilakukan melalui Forum Group Discussion (FGD) pada MGMP dan uji keterbacaan ahli dan praktisi. Uji coba ini dilakukan melalui metode deskriptif, menghasilkan data deskriptif, dianalisis, dan hasilnya dipakai untuk revisi draf model (model konseptual). Hasil di lapangan menunjukkan bahwa model PKB ini cukup baik dan memiliki keterbacaan yang cukup mudah. Penggunaan IT dianggap memudahkan guru PAI dalam pengisian instrumen. Pada guru PAI SD yang berjumlah 20 orang, terdapat sebaran skor yang tinggi. Skor berkisar pada 18 s.d. 20. Hal ini menunjukkan tanggapan yang tinggi berada pada kisaran $80 \%$ s.d 100\%. Dalam hal ini, tanggapan mereka terhadap piranti uji coba ini dipandang baik.

Program PKB guru PAI di Kota Sukabumi berhubungan dengan implementasi Permenegpan dan Reformasi Birokrasi Nomor 16 Tahun 2009. Pada dua peraturan ini, Pengembangan Keprofesian Berkelanjutan (PKB) adalah merupakan pengembangan kompetensi guru yang dilaksanakan sesuai dengan kebutuhan, kebertahapan, dan berkelanjutan dalam kerangka peningkatan profesionalitas. Hal ini dikuatkan pernyataan pengurus MGMP PAI Kota Sukabumi bahwa PKB guru PAI dilakukan untuk menciptakan guru profesional, mampu menumbuhkembangkan minat dan bakat peserta didik sesuai dengan bidangnya dalam menguasai PAI. Tujuan program PKB guru PAI ini seleras dengan pengembangan kompetensi yang dikuatkan dengan pola 
pengembangan yang berbasis karakter dengan mendinamiskan tiga pilar karakter utama yaitu keunggulan (excelence), kemauan kuat (passion) dan etika (ethical).

Excelence (keunggulan) mempunyai makna bahwa Guru Pendidikan Agama Islam harus memiliki keunggulan tertentu dalam bidang dan dunianya dengan cara: a). Commitment atau purpose yaitu memiliki komitmen untuk senantiasa berada dalam koridor tujuan dalam melaksanakan kegiatannya demi mencapai keunggulan. b). Opening your gift atau ability, yaitu memiliki kecakapan dalam menemukan potensi dirinya.c). Being the farst and the best you can be yaitu memilki motivasi yang kuat untuk menjadi yang pertama dan terbaik dalam bidangnya. d). Continuous improvement, yaitu senantiasa melakukan perbaikan secara terus menerus.

Passion for profesionalisme yaitu kemauan yang kuat dari Guru Pendidikan Agama Islam yang secara intrinsik menjiwai keseluruhan pola-pola profesionalitas yaitu: a) Passion for knowledge yaitu semangat untuk senantiasa menambah pengetahuan baik melalui cara formal ataupun informal. b) Passion for business yaitu semangat untuk melakukan secara sempurna dalam melaksanakan usaha, tugas dan missinya. c). Passion for service yaitu semangat untuk memberikan pelayanan yang terbaik terhadap apa yang menjadi tanggung jawabnya. d) Passion for people yaitu semangat untuk mewujudkan pengabdian kepada orang lain atas dasar kemanusiaan.

Ethical atau etika yang terwujud dalam watak sekaligus menjadi fondasi utama terwujudnya profesionalitas yaitu: a) Trustworthiness yaitu kejujuran atau dipercaya dalam keseluruhan kepribadian atau prilakukanya $b$ ). Responsibility yaitu tanggung jawab terhadap dirinya, tugas profesinya, keluarga, lembaga, bangsa dan terhadap Allah Swt. c) Respect, yaitu sikap untuk menghormati siapapun yang terkait langsung atau tidak langsung terhadap profesinya d) Fairnes yaitu tanggung jawab terhadap dirinya, tugas profesinya, keluarga, lembaga, bangsa dan terhadap Allah swt. e) Fairnes yaitu melaksanakan tugas secara konsekwen sesuai ketentuan 
peraturan yang berlaku g) Care yaitu penuh kepedulian terhadap berbagai hal yang terkait dengan tugas profesinya f) Citizenship yaitu menjadi warga negara yang memahami sesluruh hak dan kewajibannya serta mewujudkannya dalam prilaku profesinya.

Tujuan yang dikembangkan ini sesuai dengan semangat Permenegpan dan Reformasi Birokrasi Nomor 16 Tahun 2009 dan KMA Nomor 211 Tahun 2011 tentang Pedoman Pengembangan Standar Nasional PAI pada Sekolah. Tujuan ini bersinggungan pula dengan Pedoman PKB Guru versi Kemendikbud, yaitu meningkatkan kualitas layanan pendidikan di sekolah/madrasah dalam rangka meningkatkan mutu pendidikan. Sementara tujuan khususnya antara lain: 1) memfasilitasi guru untuk terus memutakhirkan kompetensi yang menjadi tuntutan ke depan berkaitan dengan profesinya; 2) memotivasi guru agar memiliki komitmen melaksanakan tugas pokok dan fungsinya sebagai tenaga profesional; 3) mengangkat citra, harkat, martabat profesi guru, rasa hormat dan bangga kepada penyandang profesi guru.

Peraturan Pemerintah Nomor 55 Tahun 2007, dinyatakan bahwa pengelolaan pendidikan agama dan pendidikan keagamaan berada pada Kementerian Agama RI. Sebagai pengelola pendidikan agama, Kementerian Agama berkewajiban menjamin mutu Pendidikan Agama di sekolah. Dalam rangka penyelenggaraan Pendidikan Agama Islam (PAI) yang bermutu dan sesuai dengan kebutuhan masyarakat, maka Kementerian Agama perlu membuat pengembangan terhadap delapan SNP yang telah ditetapkan oleh BSNP.

Program PKB dilakukan oleh pihak Kanwil Kementerian Agama RI. Kota Sukabumi menjadi salah satu sasarannya. Narasumber kegiatan ini merupakan tim yang ditunjuk oleh Direktorat PAI Kementerian Agama. Fenomena ini menunjukkan bahwa secara internal, Kantor Kementerian Agama Kota Sukabumi c.q. Seksi PAI belum memiliki program mandiri mengenai PKB guru PAI.

Program PKB di Kota Sukabumi hanya menjadi salah satu sasaran dari beberapa pilot project 
Direktorat Kementerian Agama. Begitu pula, program PKB PAI perspektif Direktorat PAI Kementerian Agama baru menjadi salah satu program prioritas PAI pada tahun 2017. Selang waktu satu tahun dengan tahun 2018, secara struktural belum terdapat pengembangan lebih lanjut. Optimalisasi program PKB PAI lebih banyak dilakukan oleh pengawas dengan berbagai kegiatan yang berhubungan dengan peningkatan mutu pembelajaran dan dorongan untuk publikasi ilmiah. Seksi PAI Kota Sukabumi menyelaraskan program PKB PAI sesuai dengan program Direktorat PAI.

Fenomena di lapangan menunjukkan belum adanya program yang didesain secara strategis dalam konteks PKB ini. Pengembangan mutu lebih banyak dilakukan pada tingkat sekolah dan $\mathrm{KKG}$, keterlibatan pengawas PAI, juga beberapa kegiatan workshop yang berada dalam naungan DIPA Seksi PAIS Kantor Kementerian Agama Kota Sukabumi.

Supervisi pengawas PAI sesuai dengan tupoksi masingmasing terus dilakukan. Pengawas PAI dalam hal ini menjalankan perencanaan, proses, dan evaluasi supervisi akademik pada pembelajaran PAI. Kegiatan ini dilakukan terus menerus sesuai dengan jadwal supervisi. Namun, apabila dihubungkan dengan pengembangan PKB guru PAI SD, sampai pada tahun 2017 belum tampak massif. Program PKB guru PAI, walaupun personalnya diangkat oleh Dinas Pendidikan, tetap pembinaannya diarahkan kepada Kementerian Agama RI, dalam hal ini Seksi PAI Kota Sukabumi. Kewenangan ini selaras dengan amanat PP Nomor 55 Tahun 2007 tentang Pendidikan Agama dan Pendidikan Keagamaan

Guru PAI di Kota Sukabumi dengan desain yang dibuat melaksanakan PKB yang dimulai dari Penilaian Kinerja dan Pemetaan Kompetensi. Walaupun belum sepenuhnya dilaksanakan oleh guru, responsi mereka terhadap kegiatan ini dipandang bagus. Desain PKB PAI berbeda dengan PKB guru lainnya. Pada guru lain keterlibatan yang massif muncul mulai dari LPMP, Dinas Pendidikan, dan KKG dan MGMP. Sementara pada guru PAI, desain ini diadopsi dari program 
Direktorat PAI Kementerian Agama RI yang tidak melibatkan unsur LPMP dan Dinas Pendidikan, melainkan keterlibatan pada tahap KKG dan MGMP, Seksi PAI pada Kementerian Agama Kota Sukabumi, juga Pengawas PAI.

Evaluasi ini berkaitan dengan pengujian hasil-hasil sebagai pencapaian tujuan-tujuan paling sering dilakukan dalam hampir semua model evaluasi. Perbedaannya dapat dikategorikan kedalam model yang mengutamakan hasil pembelajaran (perubahan tingkah laku) dan yang terfokus pada tujuan khusus program. Adapun model-model tersebut adalah model Tylerian, model evaluasi pembelajaran, model tujuan khusus program.

$$
\text { Program PKB yang }
$$
dilaksanakan di Kota Sukabumi mengacu kepada aspek teoritis yang dikembangkan pada Permenagpan dan RB Nomor 16 tahun 2009 tentang Jabatan Fungsional Guru dan KMA Nomor 211 Tahun 2011 tentang Pedoman Pengembangan Standar Nasional PAI pada Sekolah. Asumsi yang dikembangkan pada pelaksanaan program ini sesuai dengan
Permenagpan dan RB Nomor 16 tahun 2009 tentang Jabatan Fungsional Guru apabila dianalisis dapat diuraikan sebagai berikut:

1. Pendidikan merupakan suatu proses yang sangat strategis dalam mencerdaskan kehidupan bangsa, sehingga harus dilakukan secara profesional. Oleh sebab itu, guru sebagai salah satu pelaku pendidikan haruslah seorang yang profesional. Dengan demikian keberadaan guru di dalam proses pendidikan dapat bermakna bagi masyarakat dan bangsa. Kebermaknaan guru bagi masyarakat akan mendorong pada penghargaan yang lebih baik dari masyarakat kepada guru.

2. Guru diharapkan mampu berpartisipasi dalam pembangunan nasional untuk mewujudkan insan Indonesia yang bertakwa kepada Tuhan Yang Maha Esa, unggul dalam ilmu pengetahuan dan teknologi, memiliki jiwa estetis, etis, berbudi pekerti luhur, dan berkepribadian. Tidaklah berlebihan kalau dikatakan bahwa masa depan masyarakat, bangsa dan negara sebagian 
besar ditentukan oleh guru. Oleh sebab itu, profesi guru perlu dikembangkan secara serius dan proporsional menurut jabatan fungsional guru.

3. Agar tugas dan fungsi yang melekat pada jabatan fungsional guru dilaksanakan sesuai dengan aturan yang berlaku. Dengan demikian maka mutlak diperlukan penilaian terhadap pelaksanaan tugas dan kewajiban guru dalam melaksanakan pembelajaran/pembimbingan, dan/atau tugas-tugas tambahan yang relevan dengan fungsi sekolah/madrasah. Penilaian ini dilakukan untuk menjamin terjadinya proses pembelajaran yang berkualitas di semua jenjang pendidikan.

4. Untuk menilai kemampuan guru dalam menerapkan semua kompetensi dan keterampilan yang diperlukan pada proses pembelajaran, pembimbingan, atau pelaksanaan tugas tambahan yang relevan dengan fungsi sekolah/madrasah. Dengan demikian, profil kinerja guru sebagai gambaran kekuatan dan kelemahan guru akan teridentifikasi dan dimaknai sebagai analisis kebutuhan atau audit keterampilan untuk setiap guru, yang dapat dipergunakan sebagai basis untuk merencanakan PKB.

Evaluasi program PKB diarahkan pada beberapa hal. Pertama, aspek teoritis yang menjadi landasan pengembangan. Kedua, perencanaan desain program PKB. Ketiga, desain PKB PAI. Keempat, pelaksanaan PKB PAI, khususnya pada guru program PKB PAI tidak terlaksana sepenuhnya terutama pada aspek pengembangan program kedua sampai kedelapan. Analisis terhadap hal ini adalah sebagai berikut:

1. Program PKB PAI di Kota Sukabumi menunggu pengembangan dari pusat. Hal ini menyebabkan keterlambatan dalam implementasi pada tingkat lokal. Kenyataan ini didukung oleh fakta bahwa program ini dalam perspektif Direktorat PAI terutama pada tahun 2017 sampai 2018 masih pada tahap piloting dan pelatihan bagi pelatih inti pada setiap jenjang di tingkat pusat, provinsi, dan kabupaten/kota. 
2. Pengembangan pedagogik I yaitu perencanaan pembelajaran merupakan inisiatif pengawas setelah pelaksanaan PK online dan pelatihan pusat di tingkat provinsi yang melibatkan guru dan pengawas PAI. Peserta yang terlibat di antaranya adalah guru dan pengawas PAI di Kota Sukabumi. Kenyataan ini menunjukkan bahwa program pelatihan PKB guru PAI belum masuk pada tahap implementasi untuk guru secara langsung, melainkan untuk pelatih inti.

3. Pengembangan program kedua sampai kedelapan, yang di dalamnya terdapat pelatihan profesional untuk penyusunan penelitian dan buku, belum terlaksana. Ketidakterlaksanaan ini dipengaruhi oleh program pusat yang belum mengarah pada aspek tersebut dalam konteks pelatihan langsung pada sasaran guru PAI.

Program PKB PAI perlu difasilitasi dengan penganggaran dalam implementasinya. Dalam konteks Seksi PAI Kota Sukabumi, penganggaran PKB PAI belum nampak mewujud terutama pada tahun anggaran 2017 dan 2018 (ketika penelitian ini dilaksanakan). Kegiatan Pelatihan Perencanaan Pembelajaran dilaksanakan melalui supervisi pengawas PAI terutama dalam supervisi akademik.AI jenjang SD,SMP,SMA dan SMK di Kota Sukabumi.

Berdasarkan hasil penelitian di atas, dapat diuraikan beberapa keunggulan dan keterbatasan program PKB guru PAI di Kota Sukabumi, khususnya pada Guru PAI SD, SMP, SMA dan SMK Keunggulan program ini adalah:

1. Respon guru terhadap program ini cukup bagus. Mereka beranggapan bahwa untuk guru PAI hal ini baru dilaksanakan secara terstruktur sesuai dengan program Direktorat Pendidikan Agama Islam Kementerian Agama RI.

2. Perluasan dalam cakupan aspek kompetensi guru. Bagi guru PAI, kompetensi lain yaitu spiritual dan leadership menguatkan posisi guru dalam ranah hubungan antara tugas dengan tanggungjawab mengenyam amanah sebagai pendidik. Kompetensi ini tidak ditemukan pada guru lain. KMA Nomor 211 Tahun 2011 sebagaimana dijelaskan di atas 
memiliki alasan yang tepat yang membedakan guru PAI dengan guru lain. Guru PAI harus memiliki kelebihan daripada guru lain, karena pertimbangan materi PAI dan hubungan mereka dengan masyarakat dan sekolah terutama dalam menciptakan budaya keagamaan di sekolah.

Program PKB guru PAI telah menggunakan piranti IT yang cukup mumpuni. Penggunaan piranti ini memudahkan teknis bagi guru dalam melakukan evaluasi diri dan pemetaan kompetensi. Pada guru lain, piranti ini belum ditemukan secara massif di lapangan.

1. Adapun keterbatasan Masih banyak guru PAI yang tidak dapat menggunakan piranti IT dengan lancar. Hal ini terutama terjadi pada guru PAI dengan usia tua. Kondisi ini mendorong pengembang PKB PAI untuk melatih guru secara teknis dalam mengaplikasikan piranti IT.

2. Dukungan dari pengembang teknis PKB PAI cenderung lemah. Kelemahan ini dapat ditandai dengan lemahnya penguatan kebijakan PKB PAI dari Seksi PAI Kantor Kementerian Agama Kota Sukabumi, begitu pula teknis operasional di KKG dan MGMP PAI.

3. Keterlibatan kepala sekolah cenderung lemah. Kepala Sekolah cenderung memantau dan mengembangkan PKB guru lain, sementara pada guru PAI kurang menyentuh. Padahal, sekolah merupakan unit terdekat bagi guru PAI dalam mengembangkan rencana pengembangan profesionalitasnya.

Penelitian ini lebih cenderung mengarah pada model perencanaan PKB guru PAI, belum menyentuh langsung pada pengalaman mengenai pelaksanaan PKB guru PAI setelah menyusun perencanaan berdasarkan evaluasi dan pemetaan kompetensi. Kelemahan ini dikuatkan pada sebuah fakta bahwa PKB guru PAI secara nasional masih dalam tahap penerapan evaluasi diri dan pemetaan kompetensi. Adapun tahapan pelaksanaannya terutama pelatihan yang berhubungan dengan aspek kompetensi guru PAI belum terlaksana. Begitu pula, asumsi ini dikuatkan bahwa masa 
pelaksanaan PKB guru PAI cukup lama waktu yang diperlukan dalam masa kenaikan pangkat dan jabatan guru.

Program PKB guru PAI di Kota Sukabumi tidak semuanya berjalan lancar. Pelaksanaan program PKB guru PAI masih berjalan pada tahap evaluasi diri dan pemetaan kompetensi. Dalam hal pengembangan kompetensi guru PAI ini, dapat dilakukan beberapa strategi, yaitu:

1. PKB guru PAI perlu melibatkan stakeholders lain seperti Kepala Sekolah sebagai pimpinan terdekat guru di sekolahnya juga koordinasi dengan Dinas Pendidikan sebagai instansi pembina guru PAI yang diangkat oleh Pemda.

2. Pembinaan dan pengembangan profesi guru diorientasikan pada program penelitian, pengujian kemampuan, dilaksanakan secara kolegialitas, berfokus pada partisipasi guru, dan membantu guru-guru yang dipandang masih lemah pada beberapa aspek kompetensi.

3. Pengembangan profesionalisme guru menjadi perhatian secara global, karena guru memiliki tugas dan peran bukan hanya memberikan informasiinformasi ilmu pengetahuan dan teknologi, melainkan juga membentuk sikap dan jiwa yang mampu bertahan.

4. Pengembangan profesi guru PAI dilakukan dengan pencermatan lingkungan. Dalam hubungan ini, faktor birokrasi, khususnya birokrasi pendidikan sering kurang/ tidak mendukung bagi terciptanya suasana yang kondusif untuk pengembangan profesi tenaga pendidik.

5. Perlu dikembangkan strategi yang tepat dalam upaya menciptakan iklim kondusif bagi pengembangan profesi guru PAI.

6. Strategi yang dapat dikembangkan dalam pengembangan profesi guru di antaranya adalah: 1) Strategi perubahan paradigma. Strategi ini dimulai dengan mengubah paradigma birokasi agar menjadi mampu mengembangkan diri sendiri sebagai institusi yang berorientasi pelayanan, bukan dilayani; 2) Strategi debirokratisasi. Strategi ini dimaksudkan untuk mengurangi 
tingkatan birokrasi yang dapat menghambat pada pengembangan diri pendidik.

7. Pengembangan profesi guru PAI diarahkan untuk pengembangan inovasi. Inovasi ini akan memberikan dampak positif bagi pengembangan profesionalitas.

8. Pengembagan program PKB guru PAI dalam kerangka penguatan profesionalitas guru dapat dilakukan dengan berjenjang dengan pelatihan khusus. Pelatihan jenis ini dilaksanakan di lembagalembaga pelatihan yang diberi wewenang. Pelatihan khusus disediakan berdasarkan kebutuhan khusus atau disebabkan adanya perkembangan baru dalam keilmuan tertentu.

9. Pelatihan profesionalisme guru PAI dapat pula melibatkan di perguruan tinggi atau lembaga pendidikan lainnya. Hal ini dimaksudkan untuk melatih meningkatkan kemampuan guru dalam beberapa kemampuan seperti kemampuan melakukan penelitian tindakan kelas, menyusun karya ilmiah (Rahyasih dkk, 2020), merencanakan, melaksanakan dan mengevaluasi pembelajaran, dan lain-lain sebagainya.

10. Kepala Sekolah dalam konteks pengembangan profesi guru PAI dapat melakukan pembinaan internal sekolah dengan arahan Pengawas PAI.

11. Kelemahan guru PAI dalam melakukan diskusi masalahmasalah pendidikan dapat ditengarai dengan kegiatan secara berkala dengan topik diskusi sesuai dengan masalah yang dialami di sekolah.

Pengembangan profesi guru PAI meskipun didesain dengan program yang bagus, yang dalam hal ini mengadopsi program PKB PAI Dipai Kementerian Agama RI, tidak akan optimal jika guru tidak dapat mengembangkan kreativitas. Pengembangan kreativitas ini menjadi salah satu unsur kemandirian guru PAI dalam meningkatkan kinerja baik pada aspek amanah mulia maupun pertanggungjawaban pada aspek tugas. Hal ini dikuatkan berdasarkan asumsi Al-khalili (2006) yang menjelaskan bahwa kreativitas seseorang merupakan perwujudan kemandirian, yaitu 
proses yang dilalui oleh seorang individu di tengah-tengah pengalamannya dan yang menyebabkan untuk memperbaiki dan mengembangkan dirinya.

Tingkat keberhasilan program PKB ini dapat dianalisis melalui konfirmasi terhadap tujuan PKB. Program PKB sesuai dengan pengembangan yang diharapkan belum semuanya mencapai hasil memuaskan. Program ini membutuhkan waktu yang cukup lama dan melibatkan berbagai stakeholder peningkatan mutu. Namun walaupun begitu, terdapat beberapa tingkat keberhasilan, di antaranya adalah:

1. Terdapat peningkatan kompetensi dan kinerja Guru PAI, terutama pada aspek perencanaan pembelajaran.

2. Peningkatan mutu pembelajaran PAI sesuai dengan kinerja supervisi akademik pengawas.
3. Terdapat inserting penangkalan pemahaman islam radikal dan Gerakan Revolusi Mental (Penguatan Pendidikan Karakter pada PAI)

4. Peningkatan pemahaman mengenai pembelajaran abad 21.

5. Terwujudnya pemetaan kompetensi guru PAI di tingkat Kota Sukabumi.

6. Terciptanya proses evaluasi dan Quality Control Hasil Pelatihan Guru PAI secara berjenjang.

\section{KESIMPULAN}

Kesimpulan penelitian ini menunjukkan bahwa program PKB dapat meningkatkan kompetensi dan kinerja Guru PAI secara terukur, sistematis, dan berkelanjutan.

\section{DAFTAR PUSTAKA}

Al-Khalili, Amal Abdussalam. (2006). Mengembangkan Kreativitas Anak. Jakarta: Pustaka Al-Kautsar.

Borg, Walter R. dan Gall, M, Damien. (2007). Educational Research: An Introduction, Fifth Edition. New York: Longman.

Dasuki, Ahmad. (2010). Pengembangan Profesionalisme Guru. Manajerial, 9 (17),1-9. 
Direktorat Pendidikan Agama Islam. (2016). Rancangan Proyek Perubahan PAI, Jakarta: Kementerian Agama RI.

Gay, L.R. (1991). Educational Evaluation and Measurement: Com-petencies for Analysis and Application. Second edition. New York: Macmillan Publishing Company.

Muhaimin. (2011). Pemikiran dan Aktualisasi Pengembangan Pendidikan Islam. Jakarta: Raja Grapindo persada.

Muhaimin. (2013). Rekontruksi Pendidikan Islam. Depok: Raja grafindo Persada.

Sukmadinata, Nana Syaodih. (2010). Metode Penelitian Pendidikan. Bandung: Rosda Karya.

Ramli, Tengku Amir. (2005). Menjadi Guru Kaya: Melalui Perubahan Paradigma To Be Quadran. Bekasi: Pustaka Inti.

Rahyasih, Yayah., Hartini, Nani \& Syarifah, Liah Siti. (2020). Pengembangan Keprofesian Berkelanjutan: Sebuah Analisis Kebutuhan Pelatihan Karya Tulis Ilmiah bagi Guru. Jurnal Penelitian Pendidikan, 20 (1), 136- 144 Subhan. (2017). Faktor - Faktor Determinan Yang Mempengaruhi Kinerja Mengajar Guru Bahasa Arab Madrasah Ibtidaiyah Di Provinsi Banten, dalam repository.upi.edu, perpustakaan.upi.edu diakses pada tanggal 1 Juli 2020. 